\title{
The Use of Rewards in Improving Self-Efficacy
}

\author{
Andy Sapta \\ Lecturer of Mathematics \\ School of Management and Computer Informatics of Royal \\ Student of Doctoral Program Education Technology, State University of Medan \\ Corresponding email: sapta@royal.ac.id
}

Edi Syahputra

State University of Medan

Medan, Indonesia

Abdul Hamid K.

State University of Medan

Medan, Indonesia

\begin{abstract}
This research problem is caused by the low interest of students in following discrete mathematics lectures. The purpose of this study is to determine the use of learning methods with the provision of rewards in improving student self-efficacy. The population of this study is the second semester students STMIK Royal Kisaran which amounted to 512 people. The sample was obtained by using cluster random sampling method. The sample of research is four classes from 13 existing classes. Implementation of this research by giving rewards and ranking to students who are able to complete the given problem. Technique of collecting data by using test and questionnaire which given to student which become sample. Research data show that by applying this method of learning can improve self efficacy in following lectures on discrete mathematics courses.
\end{abstract}

Keywords: reward, ranking, self efficacy, discrete mathematics

\section{INTRODUCTION}

Currently the campus in the field of computers is growing, both in the computer program and in the form of STMIK (school of management and computer informatics) or AMIK (collage of management and computer informatics). In the curriculum of computer courses either information systems, computer systems, computer science, or the other is not independent of the mathematics courses. But there are students who do not realize that in the computer study program there is a mathematics course. Some students consider mathematics a frightening specter [1]. Many early semester students are unaware that one of the first skills to be mastered is mathematics.

In everyday life, the math has an important role. The important role of mathematics demand students to be able to be mastery of math. Mathematics needs to be given to all students to supply the students with the ability to think logically, analytical, systematic, critical, and creative, and the ability to cooperate [2]. Mathematics is a science that reviewing the abstract of object and priority the deductive reasoning, the properties of mathematical sciences would make difficulting for students to learn mathematics [3].

To address the needs of mathematics in computer learning, many campuses in the computer field incorporate several courses of mathematics in the curriculum. One such course is discrete mathematics. Discrete mathematics aims to improve students' mathematical thinking skills.

To achieve that goal, the researcher transformed the learning of teacher center into a learning that apply the competition in learning. This competition is in the form of solving the problems given by lecturers. Furthermore, for students who are able to answer questions properly and correctly will be given points. From the existing points then the students will be given a rating. This rating provides students with increased self-efficacy especially in discrete mathematics courses. self efficacy is one of the important factors in learning mathematics [4], because the passion of learning can improve learning outcomes [5]

\section{METHOD}

This type of research is quasi experiment. The group used in this study consisted of two groups. One group as a control group used conventional learning method that are teacher center, and one group as an experimental group apply competition in learning by giving reward and ranking.

This research was conducted at STMIK Royal, Kisaran, North Sumatra. The population of this study is the student of the study program of information systems in the even semester of academic year 2016/2017. The study population is 512 students divided into 13 classes. The sample of this research is obtained by using cluster random sampling technique. The study sample consisted of four classes, two classes for the experimental group and two classes for the control group.

This research data is a quantitative data in the form of student self-efficacy data on discrete mathematics course. Research data in the form of question and answer result at the 
beginning of learning and at the end of learning related to student self-efficacy toward learning in discrete mathematics course.

Quantitative technique were used in the analysisof data. Data were analysed by using the SPSS statistics program. To determine the teaching method differences of self-efficacy scores indefendent sample $\mathrm{t}$ test were used. To find out relationship between apply competition in learning by giving reward and ranking and used conventional learning method, a Pearson product-moment correlation was applied to the data.

\section{RESULT AND DISCUSSION}

To improve students' self-efficacy especially in discrete mathematics courses, researchers change the learning of teacher centers into lessons that apply competition and ranking in learning. The competition in this research is the students in the class competing to answer the questions given by lecturers. This question is a discrete mathematical problem given at the beginning of the lesson. The question comes from the material that has been learned from the previous meeting. Each student is allowed to answer all questions given at each meeting. But if he has answered correctly given the problem then he should not answer the other questions. Each lecturer meeting gives five questions to answer.

Any questions answered correctly by the students, then the student is given a gift of stars. At the end of the question and answer session, the lecturer will announce the number of stars earned by the students. Then the lecturer will sum the stars acquired at the meeting with the previous meeting. Lecturers rank students based on the number of stars they get. Lecturers congratulate the students who earned the stars. Lecturers then give encouragement to students who have not yet earned a star. Students are motivated to study harder so that the next meeting gets a star.

The means and standard deviations of the pre-test selfefficacy of the use of reward and ranking methods of teaching mathematics in discrete mathematics courses for survey items appears shown in the table.

The data in table 1 and table 2 it was found that before treatment there was no significant difference from the two sample groups. Both groups of samples had statistically different values for mathematics lectuters' efficacy in teaching, make to motivate and take on responsibility, and effective teaching.

For the purpose of determining whether the method of learning with respect and self-efficacy beliefs on the teaching of mathematics on discrete mathematics shows significant differences according to sample groups, independent t-test was applied to the data with a significance level of 0.05

As seen from table 5 independent t-test results show that there is no significant statistical difference between averages $\left(\mathrm{t}_{(144)}=0.900, \mathrm{p}<0.05\right)$

After reporting different treatment in both groups, in table 3 and table 4 it is known that there are differences of selfefficacy from both groups of samples. in the experimental group who reported treatment by giving rewards and ranking on learning had a higher value than the control group treated by conventional methods.

For the purpose of determining whether the experimental group who reported treatment by giving rewards and ranking on learning had a higher value than the control group treated by conventional methods, independent t-test was applied to the data with a significance level of 0.05

TABLE I. DESCRIPTIVE STATISTICS OF DIMENSION OF BEFORE LEARNING MODEL AT EXPERIMENT CLASS

\begin{tabular}{|c|c|c|c|c|c|}
\hline Item & $\mathbf{N}$ & Lowest Score & Highest Score & Mean & SD \\
\hline Mathematics lectuters' efficacy in teaching & 70 & 8 & 21 & 15.62 & 2.58 \\
\hline Make to Motivate and Take on Responsibility & 70 & 15 & 26 & 22.17 & 2.81 \\
\hline Effective Teaching & 70 & 7 & 22 & 14.82 & 2.15 \\
\hline
\end{tabular}

TABLE II. DESCRIPTIVE STATISTICS OF DIMENSION OF BEFORE LEARNING MODEL AT CONTROL CLASS

\begin{tabular}{|c|c|c|c|c|c|}
\hline Item & $\mathbf{N}$ & Lowest Score & Highest Score & Mean & SD \\
\hline Mathematics lectuters' efficacy in teaching & 71 & 7 & 22 & 16.71 & 2.42 \\
\hline Make to Motivate and Take on Responsibility & 71 & 14 & 24 & 20.98 & 2.15 \\
\hline Effective Teaching & 71 & 8 & 20 & 12.85 & 2.25 \\
\hline
\end{tabular}

TABLE III. DESCRIPTIVE STATISTICS OF DIMENSION OF AFTER LEARNING MODEL AT EXPERIMENT CLASS

\begin{tabular}{|c|c|c|c|c|c|}
\hline Item & $\mathbf{N}$ & Lowest Score & Highest Score & Mean & SD \\
\hline Mathematics lectuters' efficacy in teaching & 70 & 21 & 27 & 24.83 & 1.56 \\
\hline Make to Motivate and Take on Responsibility & 70 & 23 & 28 & 25.12 & 1.34 \\
\hline Effective Teaching & 70 & 18 & 25 & 22.56 & 1.75 \\
\hline
\end{tabular}

TABLE IV. DESCRIPTIVE STATISTICS OF DIMENSION OF AFTER LEARNING MODEL AT CONTROL CLASS

\begin{tabular}{|c|c|c|c|c|c|}
\hline Item & $\mathbf{N}$ & Lowest Score & Highest Score & Mean & SD \\
\hline Mathematics lectuters' efficacy in teaching & 71 & 12 & 25 & 18.85 & 2.18 \\
\hline Make to Motivate and Take on Responsibility & 71 & 17 & 26 & 23.12 & 2.12 \\
\hline Effective Teaching & 71 & 15 & 23 & 18.59 & 2.15 \\
\hline
\end{tabular}


TABLE V. T TEST BY SAMPLE GROUPS OF BEFORE LEARNING MODEL

\begin{tabular}{|l|c|c|c|c|}
\hline \multicolumn{1}{|c|}{ Group } & N & df & t & p \\
\cline { 1 - 2 } Experiment Class & 70 & \multirow{2}{*}{139} & 0.900 & 0.370 \\
\hline Control Class & 71 & & & \\
\hline
\end{tabular}

As seen from table 6, independent t-test results show that there is significant statistical difference between averages $\left(\mathrm{t}_{(144)}=0.451, \mathrm{p}>0.05\right)$

TABLE VI. T TEST BY SAMPLE GROUPS OF AFTER LEARNING MODEL

\begin{tabular}{|l|c|c|c|c|}
\hline \multicolumn{1}{|c|}{ Group } & N & df & t & p \\
\cline { 1 - 2 } Experiment Class & 70 & \multirow{2}{*}{139} & 0.451 & \multirow{2}{*}{0.610} \\
\cline { 1 - 2 } Control Class & 71 & & \\
\hline
\end{tabular}

The relationship between mathematics teaching the method of learning with respect and self-efficacy score and the teaching of mathematics on discrete mathematics score was investigated by using pearson product-moment correlation coefficient. preliminary analyses were performed to ensure no violation of the assumptions of normality, linearity and homoscedasticity. there was a positive efficacy associated with high levels of mathematis self-efficacy

Giving rewards and ranking in learning are two things that are not separated in the treatment of learning in this study. at the beginning of the lecturers' learning give the questions given rewards. students who get rewards will collect these rewards and place themselves in the rankings according to the acquisition of rewards in the classroom.

From the results of reward research that accompanied this ranking can improve students' self-efficacy against math lessons, especially discrete mathematics. This is due to the sense of competition that is built in the classroom causing all students in the class to compete for each other to get rewards.

The sense of competition arises unwittingly by the students due to a more enjoyable learning atmosphere and no sense of burden in learning. Students feel more like learning as a fun competition rather than a sense of burden to be able to solve problems given by lecturers.

Besides that, ranking done also cause class atmosphere more cheerful so do not seen burden of student in answer question given by lecturer. the student seems to regard the lecturer's question as a draw to be obtained to please.

Different from control class using conventional method, problem given by lecturer like burden to be solved by student. so the atmosphere in the classroom looks more tense.

\section{CONCLUSION}

The use of reward and ranking method is better used in learning because it can improve student self-efficacy in learning especially in discrete mathematics course. With the increase of student self-efficacy can improve student learning outcomes.

\section{REFERENCES}

[1] Sapta. A, "Publication of the assessment learning outcomes through social media," The 1st Anual International Seminar on Transformative Education and Educational Leadership, 2016, pp. 480-483.

[2] Soviawati. E, "Pendekatan matematika Realistik (PMR) untuk meningkatkan kemampuan berfikir siswa di tingkat sekolah dasar," Jurnal Penelitian Pendidikan, vol. 12, 2012, pp. 79 - 85.

[3] Setiawan. R, "Meningkatkan hasil belajar matematika dengan menggunakan metode modelling dengan alat peraga. Jurnal Mathematics Paedagogic, vol. III, 2012, pp. $28-38$.

[4] Dede. Y, “ Matematik ogretmenlerinin ogretimlerine yonelik ozyeterlik inanclari," The Journal of Educational Science, vol. VI, 2008, pp. $741-$ 757

[5] Perepiczka. M., Chandler. N, \& Becerra. M, "Relations between raduate students' statistics self-efficacy, statistics anxietty, attitude toward statistics, and social support," The Professional Counselor: Research and Practice, vol. I, 2011, pp. $99-108$ 